\title{
Influencing factors on the suitability of organ-cultured corneas
}

J-C Gavrilov', VM Borderie ${ }^{1}$, L Laroche ${ }^{1}$ and B Delbosc ${ }^{2}$

\begin{abstract}
Purpose To determine the factors related to donor and tissue retrieval, which influence the suitability of organ-cultured corneas for transplantation.
\end{abstract}

Patients and methods We retrospectively analysed 2596 donor corneas. Polytomic logistic regression analysis was used to assess the influence of various factors (that is, donor age, cause of death, death-to-tissue retrieval time, tissue retrieval-to-reception time, and tissue retrieval method) on the suitability of grafts for transplantation. Positive predictive values (PPVs) were computed.

Results Forty-three percent (1118/2596) of corneas were discarded. The leading cause for discarding corneas was poor endothelial quality $\mathbf{( 2 1 . 5 \% )}$. Corneas from donors older than 80 years were more likely to be discarded because of endothelial insufficiency $(\mathrm{OR}=2.37, P=0.001)$. Longer time between death and tissue retrieval was associated with increased risk of positive serology $(O R=1.43$, $P=0.02)$. Increased time between tissue retrieval and reception was associated with increased risk of contamination $(O R=1.57$, $P=0.03)$. PPV increased from $38.5 \%$ for corneas retrieved from donors older than $\mathbf{8 0}$ years featuring a death-to-tissue retrieval time of more than $6 \mathrm{~h}$ and a tissue retrieval-toreception time of more than $24 \mathrm{~h}$ to $64.7 \%$ for corneas retrieved from donors younger than 80 years featuring a death-to tissue retrieval time shorter than $6 \mathrm{~h}$ and a tissue retrieval-toreception time shorter than $24 \mathrm{~h}$.

Conclusion The percentage of discarded corneas can be reduced by including donors aged 80 years or less, using a time from donor's death to tissue retrieval shorter than $6 \mathrm{~h}$, and a tissue retrieval-to-reception time shorter than $24 \mathrm{~h}$.

Eye (2010) 24, 1227-1233; doi:10.1038/eye.2009.312; published online 8 January 2010
Keywords: corneal assessment; corneal organ culture; corneal storage; corneal suitability for penetrating keratoplasty

\section{Introduction}

The initial description of the organ culture technique and evaluation of its effects on the corneal tissue was reported in the seventies by Summerlin et al. ${ }^{1}$ Following this initial description, repair of the corneal endothelium during organ culture was described by Dougman et al. ${ }^{2}$ After good clinical results of organ-cultured corneal grafts obtained from old donors were reported by Sperling et al, ${ }^{3}$ most European eye banks have progressively adopted this method for corneal tissue storage before transplantation. The criteria for tissue selection before transplantation have been described, which include assessment of the corneal endothelium during storage. This led to rejection of corneas with poor endothelial cell density after preservation. ${ }^{4-7}$

For more than 10 years, the number of corneas harvested has increased from 24763 in 1996 to 39051 in 2002 in Europe, ${ }^{8}$ and from 3073 in 1995 to 6844 in 2002 in France. ${ }^{9}$ In 2007, 32080 donor corneas were processed by European eye banks. ${ }^{10}$ However, the percentage of corneas discarded before transplantation has increased during the same period: from $40 \%$ in 1996 to 47\% in 2007 in Europe, ${ }^{10}$ and from 26\% in 1995 to $47 \%$ in 2002 in France. ${ }^{9}$ To improve donor tissue quality, several criteria have been adopted concerning donor medical history, donor serology, and corneal endothelial assessment. Application of these criteria resulted in a larger number of discarded corneas, which represents significant financial cost and wasted energy. The purpose of this study was to assess the factors that influence the suitability of organ-cultured corneas for
${ }^{1}$ Department of

Ophthalmology, Institut de la Vision, CHNO des QuinzeVingts, Université Pierre et Marie Curie-Paris6, UMR-S 968, Paris, France

${ }^{2}$ Department of Ophthalmology, Centre Hospitalier Universitaire Jean-Minjoz, Université de Franche-Comté, Besançon, France

Correspondence:

J-C Gavrilov,

Department of

Ophthalmology,

Institut de la Vision, CHNO des Quinze-Vingts, Université Pierre et Marie Curie-Paris6, UMR-S 968,

Paris, 28 rue de Charenton, Paris 75012,

France

Tel: + 3301400215 04; Fax: + 330140021599 . E-mail: jcgavrilov@ quinze-vingts.fr

Received: 28 March 2009 Accepted in revised form: 20 November 2009 Published online: 8 January 2010 
transplantation, and to describe rules that could significantly decrease the number of discarded corneas.

\section{Materials and methods}

\section{Corneal procurement}

This retrospective study used 2596 corneas with full data from 3024 corneas received at the eye bank of EFS Bourgogne-Franche-Comte (Besançon, France) between 2000 and 2003. Donor tissue material retrieval was performed by in situ excision in all cases. Only corneas with full data were included (that is, donor age, cause of death, death-to-tissue retrieval time, tissue retrieval-toreception time, organ-cultured time, and endothelial cell density). Death-to-tissue retrieval time is the time from donor's death to retrieval of the donor corneas. Tissue retrieval-to-reception time is the time from retrieval of the donor corneas to reception of tissue at the eye bank for processing and storage. No donor age limits were set. Prolonged death-to-tissue retrieval time up to $24 \mathrm{~h}$ or more and prolonged tissue retrieval-to-preservation time up to $48 \mathrm{~h}$ or more were accepted.

\section{Corneal storage}

After in situ tissue retrieval, corneas were immediately placed in preservation medium at room temperature (CorneaPrep II; Eurobio, Les Ulis, France) and transferred to the eye bank. At the eye bank, corneas were stored by organ culture at $31^{\circ} \mathrm{C}$ (CorneaMax, Eurobio) for 10-35 days. The endothelium of each cornea was observed twice: at the time of reception in the eye bank and at the end of storage. It was evaluated by light microscopy after staining with Trypan blue $(0.4 \%)$ and dilatation of intercellular spaces was induced by using normal saline. Endothelial cell density was manually estimated using a grid placed in one ocular. If one of the following was present, cornea was discarded: endothelial cell density less than 2000 cells $/ \mathrm{mm}^{2}$, endothelial cell mortality greater than $2 \%$, irregular cellular mosaic, and endothelial cells loss greater than $20 \%$ during storage. ${ }^{11}$ The sterility of cornea was evaluated by inspection of the colour of the media three times per week, and by microbiological analysis of the medium samples. Serology of the donor was analysed from a blood sample taken at the time of tissue retrieval. For corneas retrieved from a multi-organ donor, a blood sample was taken before cardio arrest. Non-contributive or unsuitable analysis was considered as positive serology. Exclusion criteria for surgical use were inadequate endothelium, contamination of the medium, positive serology of the donor, and medical contraindication or technical accident.

\section{Statistics}

\section{Univariate analysis}

The influence of donor and tissue retrieval factors on the rate of donor corneas issued for transplantation was first assessed by $\chi^{2}$-test and Fisher's exact test for qualitative factors and Student's $t$-test for quantitative factors. The following factors were recorded and analysed as predictive variables: donor age, donor cause of death, multi-organ or single-organ donor, death-to-tissue retrieval time, and tissue retrieval-to-reception time. Spearman's rank correlation was used to study the correlation between quantitative data.

\section{Multivariate analysis}

The predictive variables that were significantly $(P<0.10)$ associated with the likelihood of acceptance of donor tissue for transplantation were analysed by multivariate polytomic logistic regression. The models were set for each specific risk of unsuitability (that is, inadequate endothelium, positive serology, contamination, and other reasons). A $P$-value below 0.05 in multivariate polytomic regression was considered statistically significant. Odds ratios (ORs) were quoted for significant factors $(P<0.05)$. They show for a given factor the risk compared with the baseline. The baseline for age was donor age less than 40 years; for death-to-tissue retrieval time it was less than $6 \mathrm{~h}$; and for tissue retrieval-to-reception time it was less than $24 \mathrm{~h}$. For a given cause of death, the OR was the risk compared with all other causes of death. ORs are shown with their 95\% confidence intervals (95\% CIs) and means are given with the standard deviations (SD). No adjustment was made for statistical dependence between multiple corneas from the same donor as the analysis was based on corneas rather than on donors. Positive predictive values (PPVs) of suitability of corneas for transplantation were computed according to factors, which were shown to significantly influence suitability in multivariate logistic regression. PPVs were calculated as follows:

$\mathrm{PPV}=$ number of suitable corneas/(number of suitable corneas + number of discarded corneas).

\section{Results}

\section{Donor cornea characteristics}

In this retrospective study, 2596 corneas were included from 1333 donors. The mean donor age was $68.0 \pm 16.9$ years (SD). Seventy-four percent of donors were older than 60 years (Table 1). The most common causes of death were cardiovascular diseases $(30.7 \%)$, stroke $(22.1 \%)$, and cancer (17.6\%). Eleven percent of corneas were retrieved from a multi-organ donor. The mean time between death and tissue retrieval was $8.4 \pm 6.0 \mathrm{~h}$. The mean time between tissue retrieval and reception at 
Table 1 General data and data of suitable and discarded corneas

\begin{tabular}{|c|c|c|c|c|c|c|c|c|c|}
\hline \multirow[t]{3}{*}{ Risk factors } & \multirow{3}{*}{$\begin{array}{c}\text { General data } \\
\mathrm{n}\end{array}$} & \multicolumn{2}{|c|}{ Corneas suitable for surgery } & \multicolumn{6}{|c|}{ Corneas discarded } \\
\hline & & & & \multicolumn{2}{|c|}{ Contamination } & \multicolumn{2}{|c|}{ Positive serology } & \multicolumn{2}{|c|}{ Endothelium } \\
\hline & & $\mathrm{n}$ & $\%$ & $\mathrm{n}$ & $\%$ & $\mathrm{n}$ & $\%$ & $\mathrm{n}$ & $\%$ \\
\hline \multicolumn{10}{|c|}{ Donor age (years) } \\
\hline$<40$ & 177 & 113 & 63.8 & 15 & 8.5 & 14 & 7.9 & 24 & 13.6 \\
\hline $40-59$ & 491 & 311 & 63.3 & 41 & 8.4 & 60 & 12.2 & 58 & 11.9 \\
\hline $60-79$ & 1225 & 734 & 59.9 & 67 & 5.5 & 157 & 12.8 & 248 & 20.2 \\
\hline$>80$ & 703 & 320 & 45.5 & 34 & 4.8 & 107 & 15.2 & 228 & 32.4 \\
\hline Total & 2596 & 1478 & 56.9 & 157 & 6.0 & 338 & 13 & 558 & 21.5 \\
\hline \multicolumn{10}{|l|}{ Cause of death } \\
\hline Traumatic & 249 & 168 & 67.5 & 20 & 8.0 & 21 & 8.4 & 31 & 12.4 \\
\hline Cardiac & 798 & 429 & 53.8 & 39 & 4.9 & 110 & 13.8 & 200 & 22.2 \\
\hline Stroke & 573 & 353 & 61.6 & 30 & 5.2 & 51 & 8.9 & 127 & 22.1 \\
\hline Respiratory & 218 & 104 & 47.7 & 19 & 8.7 & 33 & 15.1 & 58 & 26.6 \\
\hline Cancer & 458 & 264 & 57.7 & 23 & 5.0 & 77 & 16.8 & 79 & 17.2 \\
\hline Intoxication & 30 & 19 & 63.3 & 3 & 10.0 & 6 & 20.0 & 2 & 6.7 \\
\hline Infection & 75 & 37 & 49.3 & 5 & 6.7 & 12 & 16.0 & 17 & 22.7 \\
\hline Others & 195 & 104 & 53.3 & 18 & 9.2 & 28 & 14.3 & 44 & 22.6 \\
\hline Total & 2596 & 1478 & 56.9 & 157 & 6.0 & 338 & 13 & 558 & 21.5 \\
\hline \multicolumn{10}{|c|}{ Harvested corneas } \\
\hline MOD & 303 & 227 & 74.9 & 23 & 7.6 & 4 & 1.3 & 35 & 11.6 \\
\hline SOD & 2293 & 1251 & 54.6 & 134 & 5.9 & 334 & 14.5 & 523 & 22.8 \\
\hline Total & 2596 & 1478 & 56.9 & 157 & 6.0 & 338 & 13 & 558 & 21.5 \\
\hline \multicolumn{10}{|l|}{ DET (hours) } \\
\hline$<6 \mathrm{~h}$ & 1247 & 730 & 58.5 & 60 & 4.8 & 135 & 10.8 & 271 & 21.7 \\
\hline $6-12 \mathrm{~h}$ & 698 & 396 & 56.7 & 55 & 7.9 & 83 & 11.9 & 148 & 21.2 \\
\hline$>12 \mathrm{~h}$ & 651 & 352 & 54.1 & 42 & 6.5 & 120 & 18.4 & 139 & 21.4 \\
\hline Total & 2596 & 1478 & 56.9 & 157 & 6.0 & 338 & 13 & 558 & 21.5 \\
\hline \multicolumn{10}{|l|}{ ERT (hours) } \\
\hline$<24 \mathrm{~h}$ & 1017 & 532 & 52.3 & 37 & 3.6 & 140 & 13.8 & 221 & 21.7 \\
\hline $24-48 \mathrm{~h}$ & 1181 & 715 & 60.5 & 75 & 6.4 & 147 & 12.4 & 255 & 21.6 \\
\hline$>48 \mathrm{~h}$ & 398 & 231 & 58 & 45 & 11.3 & 51 & 12.8 & 82 & 20.6 \\
\hline Total & 2596 & 1478 & 56.9 & 157 & 6.1 & 338 & 13 & 558 & 21.5 \\
\hline
\end{tabular}

Abbreviations: DET, death-to-excision time; ERT, excision-to-reception time; MOD, multi-organ donor; SOD, single-organ donor.

Data of corneas discarded for 'other reasons' are not shown.

$\%$ Indicates the percentage corresponding for each group of each risk factors.

Boldfaced values indicate the total for each group.

Italicized values indicate the beginning of each group.

the eye bank was $33.3 \pm 20.6 \mathrm{~h}$. The mean endothelial cell density at the time of reception at the eye bank was $2140.7 \pm 274.9$ cells $/ \mathrm{mm}^{2}$.

The percentage of discarded corneas was $43.1 \%$ (1118/2596). The first cause of unsuitability was inadequate endothelium (21.5\%, 558 corneas). Thirteen percent $(338 / 2596)$ of corneas were discarded for positive serology and $6.0 \%(157 / 2596)$ for contamination. Sixtyfive corneas $(2.5 \%)$ were discarded for 'other reasons'.

\section{Influence of donor age on suitability}

The percentage of discarded corneas ranged from $36.2 \%$ for donors younger than 40 years to $54.5 \%$ for donors older than 80. Donor age had a strong influence only for endothelial assessment (Table 2). Thirteen percent of corneas retrieved from donors younger than 40 years (baseline) did not reach the endothelial criteria, compared with $32.4 \%$ from donor older than 80 years (Table 1). The specific risk of inadequate endothelium increased only for corneas from donors older than 80 years $(\mathrm{OR}=2.37 ; P=0.001)$. The mean endothelial cell density significantly decreased with donor age from an average of $2288.5 \pm 217.8$ cells $/ \mathrm{mm}^{2}$ for corneas retrieved from donors younger than 40 years to $2059.4 \pm 313.1$ cells $/ \mathrm{mm}^{2}$ for corneas retrieved from donors older than 80 years $(P<0.001)$. This significant decrease in endothelial cell density could also be 
Table 2 Influence of factors on specific risk of inadequate endothelium, positive serology, and contamination

\begin{tabular}{|c|c|c|c|c|c|c|}
\hline \multirow[t]{2}{*}{ Risk factors } & \multicolumn{2}{|c|}{ Inadequate endothelium } & \multicolumn{2}{|c|}{ Positive serology } & \multicolumn{2}{|c|}{ Contamination } \\
\hline & OR $(95 \% C I)$ & $\mathrm{P}$ & OR $(95 \% C I)$ & $\mathrm{P}$ & OR $(95 \% C I)$ & $\mathrm{P}$ \\
\hline \multicolumn{7}{|c|}{ Donor age (years) (baseline: age $<40(n=177))$} \\
\hline $40-59(n=491)$ & $0.89(0.47-1.37)$ & 0.42 & $1.00(0.52-1.93)$ & 0.99 & $0.93(0.49-1.78)$ & 0.83 \\
\hline $60-79(n=1225)$ & $1.22(0.74-2.04)$ & 0.43 & $0.92(0.44-1.53)$ & 0.53 & $0.97(0.51-1.82)$ & 0.23 \\
\hline$>80(n=703)$ & $2.37(1.41-3.98)$ & $<0.001$ & $1.12(0.60-2.13)$ & 0.71 & $0.94(0.49-1.79)$ & 0.41 \\
\hline \multicolumn{7}{|c|}{ Harvested (baseline: $M O D(n=303))$} \\
\hline SOD $(n=2293)$ & $1.70(1.11-2.64)$ & 0.01 & $19.59(7.1-54.8)$ & 0.0001 & $0.95(0.45-2.39)$ & 0.57 \\
\hline \multicolumn{7}{|c|}{ DTT (hours) (baseline: DET $<6(n=1247))$} \\
\hline $6-12(n=698)$ & $1.02(0.81-1.31)$ & 0.81 & $1.43(1.06-1.94)$ & 0.02 & $1.04(0.87-1.59)$ & 0.14 \\
\hline$>12(n=651)$ & $0.85(0.62-1.05)$ & 0.11 & $2.32(1.74-3.10)$ & 0.0001 & $1.53(0.99-2.37)$ & 0.21 \\
\hline \multicolumn{7}{|c|}{ TRT (hours) (baseline: ERT<24 $(n=1017))$} \\
\hline $24-48(n=1181)$ & $0.94(0.32-1.54)$ & 0.24 & $0.89(0.69-1.16)$ & 0.40 & $1.57(1.04-2.37)$ & 0.03 \\
\hline$>48(n=398)$ & $1.09(0.59-1.65)$ & 0.15 & $1.08(0.75-1.57)$ & 0.67 & $2.82(1.76-4.54)$ & 0.001 \\
\hline
\end{tabular}

Abbreviations: CI, confidence interval; DTT, death to tissue retrieval time (hours); OR, odds ratio; SOD, cornea harvested from a single-organ donor; TRT, tissue retrieval to reception time (hours).

Odds ratio indicates the risk compared with the baseline. For donor age, baseline is $<40$ years. For harvested cornea, baseline is cornea harvested from a multi-organ donor. For DTT, baseline is $<6 \mathrm{~h}$. For TRT, baseline is $<24 \mathrm{~h}$.

Results for corneas discarded for 'other reasons' are not shown.

Table 3 Influence of donor age on the endothelial cell density

\begin{tabular}{|c|c|c|c|c|c|c|}
\hline & \multicolumn{6}{|c|}{ Endothelial cell density (cell/mm²) } \\
\hline & \multicolumn{2}{|c|}{ General data } & \multicolumn{2}{|c|}{$\begin{array}{l}\text { Corneas suitable for } \\
\text { transplantation }\end{array}$} & \multicolumn{2}{|c|}{$\begin{array}{c}\text { Corneas discarded for endothelial } \\
\text { non-qualification }\end{array}$} \\
\hline \multicolumn{7}{|l|}{ Donor age } \\
\hline$<40$ & $2288.5 \pm 217.8$ & $n=177$ & $2330.6 \pm 94.8$ & $n=113$ & $1934.0 \pm 389.2$ & $n=24$ \\
\hline $40-59$ & $2227.1 \pm 246.2$ & $n=491$ & $2269.3 \pm 124.9$ & $n=311$ & $1864.6 \pm 419.7$ & $n=58$ \\
\hline $60-79$ & $2139.8 \pm 250.8$ & $n=1225$ & $2217.3 \pm 126.2$ & $n=734$ & $1770.9 \pm 375.9$ & $n=248$ \\
\hline$>80$ & $2059.4 \pm 313.1$ & $n=703$ & $2199.0 \pm 121.3$ & $n=32$ & $1674.4 \pm 370.3$ & $n=228$ \\
\hline$P$-value & $<0.001$ & & $<0.001$ & & $<0.001$ & \\
\hline
\end{tabular}

observed for corneas suitable for transplantation and those discarded for endothelial non-qualification (Table 3). Donor age had no significant influences on the risk of contamination and positive serology.

\section{Influence of donor status on suitability}

For corneas retrieved from a single-organ donor, $45.4 \%$ were discarded as compared with $25.1 \%$ for corneas retrieved from a multi-organ donor. Among corneas retrieved from a single-organ donor, $14.5 \%$ were discarded for positive serology (vs 1.3\% for corneas retrieved from a multi-organ donor) and $22.8 \%$ for inadequate endothelium (vs $11.6 \%$ for corneas retrieved from a multi-organ donor) (Table 1). As compared with corneas harvested from a multi-organ donor, the specific risk of positive serology $(\mathrm{OR}=19.6, P<0.0001)$ and the risk of inadequate endothelium $(\mathrm{OR}=1.7, P=0.01)$ were significantly higher (Table 2).

\section{Influence of death-to-tissue retrieval time on suitability}

Longer time between death and tissue retrieval was associated with increased risk of positive serology: from $10.8 \%$ for the time group under $6 \mathrm{~h}$ (baseline), to $11.9 \%$ for the time group $6-12 \mathrm{~h}(\mathrm{OR}=1.43 ; P=0.02)$, and $18.4 \%$ for the time group up to $12 \mathrm{~h}(\mathrm{OR}=2.32 ; P<0.0001)$ (Table 2).

\section{Influence of tissue retrieval-to-reception time on suitability}

Increased time between tissue retrieval and reception was associated with increased risk of contamination: from $3.6 \%$ for the time group under $24 \mathrm{~h}$ (baseline), to $6.4 \%$ for the time group $24-48 \mathrm{~h}(\mathrm{OR}=1.57 ; P=0.03)$, and $11.3 \%$ for the time group up to $48 \mathrm{~h}(\mathrm{OR}=2.82 ; P<0.001)$ (Table 2). 
Table 4 Positive predictive value of suitability of corneas according to influencing factors (donor age, death-to-tissue retrieval time, and tissue retrieval-to-reception time)

\begin{tabular}{lccc}
\hline & $\begin{array}{c}\text { Number of } \\
\text { suitable corneas }\end{array}$ & $\begin{array}{c}\text { Number of } \\
\text { discarded corneas }\end{array}$ & $\begin{array}{c}\text { Suitability positive } \\
\text { predictive value (\%) }\end{array}$ \\
\hline $\mathrm{DA}<80$ years; DTT $<6 \mathrm{~h}$; TRT $<24 \mathrm{~h}$ & 381 & 208 & 64.7 \\
$\mathrm{DA}<80$ years; DTT $<6$; TRT $>24 \mathrm{~h}$ & 197 & 131 & 60.1 \\
$\mathrm{DA}<80$ years; DTT $>6$ h; TRT $<24 \mathrm{~h}$ & 384 & 253 & 60.3 \\
$\mathrm{DA}<80$ years; DTT $>6 \mathrm{~h}$; TRT $>24 \mathrm{~h}$ & 196 & 143 & 57.8 \\
$\mathrm{DA}>80$ years; DTT $<6 \mathrm{~h}$; TRT $<24 \mathrm{~h}$ & 81 & 77 & 51.3 \\
$\mathrm{DA}>80$ years; DTT $<6$; TRT $>24 \mathrm{~h}$ & 87 & 128 & 47.8 \\
$\mathrm{DA}>80$ years; DTT $>6 \mathrm{~h}$; TRT $<24 \mathrm{~h}$ & 100 & 83 & 43.9 \\
$\mathrm{DA}>80$ years; DTT $>6 \mathrm{~h}$; TRT $>24 \mathrm{~h}$ & 52 & 38.5 \\
\hline
\end{tabular}

Abbreviations: DA, donor age (years); DTT, death-to-tissue retrieval time (hours); TRT, tissue retrieval-to-reception time (hours).

It represents the likelihood for a given cornea to be suitable for transplantation according to donor age, death-to- tissue retrieval time, and tissue retrievalto-reception time.

\section{Influence of donor cause of death on suitability}

There were no significant relationships at multivariate level between the donor cause of death and each specific risk of unsuitability.

\section{Positive predictive values}

PPVs of suitability of corneas were calculated according to influencing factors (Table 4). The status of the donor (single-organ donor or multi-organ donor) was not included in this analysis as there were no multi-organ donors older than 80 years. The highest PPV (64.7\%) was found for corneas retrieved from donors younger than 80 years in the $6 \mathrm{~h}$ following the donor's death, with tissue retrieval-to-reception time shorter than $24 \mathrm{~h}$. The lowest PPV $(38.5 \%)$ was found in the opposite case (donor age $>80$ years, death-to-tissue retrieval time $>6 \mathrm{~h}$, and tissue retrieval-to-reception time $>24 \mathrm{~h}$ ).

\section{Discussion}

In the present retrospective study at a single regional eye bank, the leading cause for discarding corneas before transplantation was poor endothelial quality, which was in turn associated with donor age greater than 80 years. Longer time between death and tissue retrieval was associated with increased risk of positive serology. Increased time between tissue retrieval and reception was associated with increased risk of contamination. For corneas obtained from donors older than 80 years, the risk of inadequate endothelium increased by $2.37 \%$. Previous reports have shown that corneas retrieved from old donors were discarded in more than $50 \%$ of cases. ${ }^{5,12,13}$ For the study by Adán et $a l^{14}$ the highest proportion of corneas classified as 'Excellent' or 'Good' came from young donors. Although a considerable proportion of the donated corneas came from older donors, the majority of corneas used for optical transplants came from younger ones in this study. Our results are in accordance with those of Gain et al ${ }^{13}$ who established a difference between old and young donors only for endothelial assessment, and with Armitage et $a l^{5}$ who showed that the risk of endothelial non-qualification increased with the age of the donor. The age-related endothelial cell loss was estimated at $0.6 \%$ per year for normal patients. ${ }^{15}$ However, for corneas retrieved from old donors, the cell loss during storage was shown to be lower than for corneas retrieved from younger donors. ${ }^{4,5,13}$ In addition, after transplantation, graft survival for corneal grafts harvested from old donors was not lower than that for corneas from young donors. ${ }^{4,13}$ Even if the risk of unsuitability for endothelial non-qualification increases with donor age, the report from the New Zealand National Eye Bank did not find any relationships between donor age and overall suitability. ${ }^{16}$

In the present study, none of the causes of death showed any significant association with the different causes of unsuitability. Robert et $a l^{17}$ who conducted a specific study of corneas from septic donors did not find the risk of contamination for septic donors to be greater than that for aseptic donors. This finding was confirmed by Spelsberg et al. ${ }^{18}$ Conversely, Armitage et $a l^{5}$ reported from a large series of more than 9000 corneas an increased risk of contamination for corneas obtained from septic donors $(\mathrm{OR}=1.9)$. In the report from the New Zealand National Eye Bank, ${ }^{16}$ corneal tissue from donors with a cardiovascular or cerebrovascular cause of death was more likely to be suitable for transplantation. Nevertheless, as was discussed by the authors, the high proportion of donors from these groups (67.2\%) who died suddenly with less morbidity may account for higher suitability. Another short series suggested a possible link between post-keratoplasty endophthalmitis and donor malignancy. ${ }^{19}$ This was confirmed by a study by the Eye Bank Association of America, ${ }^{20}$ which reported that hospitalization or cancer at the time of 
death more than doubled the OR of post-keratoplasty endophthalmitis. This is possibly due to exposition of donors to nosocomial pathogens. In addition, Van Meter ${ }^{21}$ reported five cases of dense central sub-epithelial scarring after penetrating keratoplasty using corneal grafts obtained from donors with a history of cancer and systemic chemotherapy with antimetabolite drugs during the last 8 weeks before death. In all five patients, corneal epithelial damage was attributed in part to the effect of alkylating agents present in the corneal tear film.

We found a strong correlation between death-to-tissue retrieval time and the risk of positive serology. Cahane et $\mathrm{al}^{22}$ suggested that delay in harvesting corneas may give rise to false-positive serology. In contrast with previous reports, we did not find any relationships between death-to-tissue retrieval time and the risk of inadequate endothelium. ${ }^{5,23}$ Nevertheless, for Armitage et $a l^{5}$ this relationship was weak $(\mathrm{OR}=0.988)$. In the present study, the mean death-to-tissue retrieval time $(8.4 \mathrm{~h})$ was quite short as compared with that in previous reports (10-26h). $5,13,18,24,25$

We did not find any relationships between death-topreservation time and the risk of contamination, whereas previous reports had suggested that a death-topreservation time of more than $15 \mathrm{~h}$ was associated with increased risk of positive microbial rim culture. ${ }^{26}$ However, this result was significant only in univariate analysis and not in multivariate analysis. ${ }^{26}$ Interestingly, the authors showed that slit-lamp quality rating of corneal tissue was associated with the results of donor corneal rim cultures. It has been suggested that stromal oedema may allow bacteria to enter the donor cornea. ${ }^{27}$ Finally, in the New Zealand National Eye Bank report, ${ }^{16}$ the mean death-to-preservation time was $15.2 \mathrm{~h}$ and it did not differ between corneas that were suitable for transplantation and those that were unsuitable.

In the present study, the risk of contamination increased with tissue retrieval-to-reception time. Armitage et $a l^{5}$ showed weak influence of this factor on the likelihood of contamination $(\mathrm{OR}=1.004,95 \%$ $\mathrm{CI}=0.999-1.009)$. For the study by Hassan et al, ${ }^{20}$ corneas obtained and transplanted after 5 days of donation were more likely to be associated with post-keratoplasty endophthalmitis. In addition, the risk of endophthalmitis rose by $17 \%$ for every 10 years of recipient age in this study. As opposed to our results, two studies reported an influence of the tissue retrieval-to-reception time on the risk of endothelial non-qualification. ${ }^{12,23}$

\section{Conclusion}

After analysis of 2596 donor corneas processed in a unique regional eye bank and stored by organ culture, the following criteria may be used to reduce the percentage of discarded corneas: donor age 80 years or less, time from donor's death to tissue and blood sample retrieval shorter than $6 \mathrm{~h}$, and time from tissue retrieval to reception at the eye bank shorter than $24 \mathrm{~h}$.

\section{Summary}

What was known before

- To determine the factors related to donor and tissue retrieval, which influence the suitability of organ-cultured corneas for transplantation.

What this study adds

- Donor age, death-to-tissue retrieval time, and tissue retrieval-to-reception time are important predictive factors for corneal suitability

\section{Conflict of interest}

The authors declare no conflict of interest.

\section{Acknowledgements}

We thank Valerie Lapierre and Caroline Malugani for help with data collection and for technical assistance. This work was supported by UPMC University Paris 06, France.

\section{References}

1 Summerlin WT, Miller GE, Harris JE, Good RA. The organcultured cornea: an in vitro study. Invest Ophthalmol 1973; 12: 176-180.

2 Doughman DJ, Van Horn D, Rodman WP, Byrnes P, Lindstrom RL. Human corneal endothelial layer repair during organ culture. Arch Ophthalmol 1976; 94: 1791-1796.

3 Sperling S, Olsen T, Ehlers N. Fresh and cultured corneal grafts compared by post-operative thickness and endothelial cell density. Acta Ophthalmol (Copenhagen) 1981; 59: 566-575.

4 Borderie VM, Scheer S, Touzeau O, Vedie F, CarvajalGonzalez S, Laroche L. Donor organ cultured corneal tissue selection before penetrating keratoplasty. $\mathrm{Br} J$ Ophthalmol 1998; 82: 382-388.

5 Armitage WJ, Easty DL. Factors influencing the suitability of organ-cultured corneas for transplantation. Invest Ophthalmol Vis Sci 1997; 38: 16-24.

6 Schroeter J, Rieck P. Endothelial evaluation in the cornea bank. Dev Ophthalmol 2009; 43: 47-62.

7 Borderie VM. Donor selection, retrieval and preparation of donor tissue. Donor selection. Dev Ophthalmol 2009; 43: 22-30.

8 European Eye Bank Association. European Eye Bank Association Directory, 14th ed. European Eye Bank Association: Amsterdam, the Netherlands, 2006.

9 Bilan des activités de prélèvement et de greffe en France en 2004. Agence de la biomédecine. Rapport annuel 2004. Bialec: Nancy; 2005. 
10 European Eye Bank Association. European Eye Bank Association Directory, 17th ed. European Eye Bank Association: Mestre, Italy, 2009.

11 Pels E, Schuchard Y. Organ culture in the Netherlands. In: Brightbill FS (ed). Corneal Surgery. Theory, Technique and Tissue. CV Mosby: St Louis, 1993, pp 622-632.

12 Probst LE, Halfaker BA, Holland EJ. Quality of corneal donor tissue in the greater-than-75-year age group. Cornea 1997; 16: 507-511.

13 Gain P, Thuret G, Chiquet C, Rizzi P, Pugniet JL, Acquart S et al. Cornea procurement from very old donors: post organ culture cornea outcome and recipient graft outcome. Br J Ophthalmol 2002; 86: 404-411.

14 Adán CB, Diniz AR, Perlatto D, Hirai FE, , Sato EH. Ten years of corneal donation to the Hospital São Paulo Eye Bank: characteristics of cornea donors from 1996 to 2005. Arq Bras Oftalmol 2008; 71: 176-181.

15 Bourne WM, Nelson LR, Hodge DO. Central corneal endothelial cell changes over a ten-year period. Invest Ophthalmol Vis Sci 1997; 38: 779-782.

16 Patel HY, Brookes NH, Moffatt L, Sherwin T, Ormonde S, Clover GM et al. The New Zealand National Eye Bank study 1991-2003: a review of the source and management of corneal tissue. Cornea 2005; 24: 576-582.

17 Robert PY, Camezind P, Drouet M, Ploy MC, Adenis JP. Internal and external contamination of donor corneas before in situ excision: bacterial risk factors in 93 donors. Graefes Arch Clin Exp Ophthalmol 2002; 240: 265-270.

18 Spelsberg H, Reinhard T, Sengler U, Daeubener W, Sundmacher R. Organ-cultured corneal grafts from septic donors: a retrospective study. Eye 2002; 16: 622-627.
19 Keyhani K, Seedor JA, Shah MK, Terraciano AJ Ritterband DC. The incidence of fungal keratitis and endophthalmitis following penetrating keratoplasty. Cornea 2005; 24: 288-291.

20 Hassan SS, Wilhelmus KR, Dahl P, Davis GC, Roberts RT, Ross KW et al. Medical Review Subcommittee of the Eye Bank Association of America. Infectious disease risk factors of corneal graft donors. Arch Ophthalmol 2008; 126: 235-239.

21 Van Meter WS. Central corneal opacification resulting from recent chemotherapy in corneal donors. Trans Am Ophthalmol Soc 2007; 105: 207-212.

22 Cahane M, Barak A, Goller O. The incidence of hepatitis C virus positive serological test results among cornea donors. Cell Tissue Bank 2000; 1: 81-85.

23 Grabska-Liberek I, Szaflik J, Brix-Warzecha M. The importance of various factors relating to the morphological quality of corneas used for PKP by the Warsaw Eye Bank from 1996 to 2002. Ann Transplant 2003; 8: 26-31.

24 Hagenah M, Bohnke M, Engelmann K, Winter R. Incidence of bacterial and fungal contamination of donor corneas preserved by organ culture. Cornea 1995; 14: 423-426.

25 Bohringer D, Reinhard T, Spelsberg H, Sundmacher R. Influencing factors on chronic endothelial cell loss characterised in a homogeneous group of patients. $\mathrm{Br} J$ Ophthalmol 2002; 86: 35-38.

26 Hassan SS, Wilhelmus KR. Quality assessment and microbiologic screening of donor corneas. Cornea 2007; 26: 953-955.

27 Zanetti E, Bruni A, Mucignat G, Camposampiero D, Frigo AC, Ponzin D. Bacterial contamination of human organcultured corneas. Cornea 2005; 24: 603-607. 